\title{
Relative bioavailability of carnitine delivered by ruminal or abomasal infusion or by encapsulation in dairy cattle
}

\author{
K. E. Olagaray, ${ }^{*}$ J. E. Shaffer, ${ }^{*}$ C. K. Armendariz, ${ }^{*}$ A. Bellamine,† S. Jacobs,† E. C. Titgemeyer, ${ }^{\star}$ \\ and B. J. Bradford*1 \\ *Department of Animal Sciences and Industry, Kansas State University, Manhattan 66506 \\ †Lonza Inc., Allendale, NJ 07401
}

\begin{abstract}
Two studies were designed to evaluate the relative bioavailability of L-carnitine delivered by different methods in dairy cattle. In experiment 1, 4 Holstein heifers were used in a split-plot design to compare ruminally or abomasally infused L-carnitine. The study included 2 main-plot periods, with infusion routes allocated in a crossover design. Within main-plot periods, each of 3 subplot periods consisted of 4-d infusions separated with 4 -d rest periods. Subplot treatments were infusion of 1 , 3 , and $6 \mathrm{~g}$ of L-carnitine/d in conjunction with $6 \mathrm{~g} / \mathrm{d}$ of arabinogalactan given in consideration of eventual product manufacturing. Doses increased within a period to minimize carryover risk. Treatments were solubilized in $4 \mathrm{~L}$ of water and delivered in two 10-h infusions daily. Blood was collected before the start of infusion period and on d 4 of each infusion period to obtain baseline and treatment L-carnitine concentrations. There was a dose $\times$ route interaction and route effect for increases in plasma carnitine above baseline, with increases above baseline being greater across all dose levels when infused abomasally compared with ruminally. Results demonstrated superior relative bioavailability of L-carnitine when ruminal exposure was physically bypassed. In experiment 2, 56 lactating Holstein cows $(143 \pm 72 \mathrm{~d}$ in milk) were used in 2 cohorts in randomized complete block designs (blocked by parity and milk production) to evaluate 2 rumen-protected products compared with crystalline L-carnitine. Treatments were (1) control, (2) $3 \mathrm{~g} / \mathrm{d}$ of crystalline L-carnitine (crystalline), (3) 6 $\mathrm{g} / \mathrm{d}$ of crystalline, (4) $5 \mathrm{~g} / \mathrm{d}$ of $40 \mathrm{COAT}$ (40\% coating, $60 \%$ L-carnitine), (5) $10 \mathrm{~g} / \mathrm{d}$ of $40 \mathrm{COAT}$, (6) $7.5 \mathrm{~g} / \mathrm{d}$ of 60COAT (60\% coating, 40\% L-carnitine), and (7) 15 $\mathrm{g} / \mathrm{d}$ of 60COAT. Treatments were top-dressed to diets twice daily. Each cohort used 14-d and included a 6-d baseline measurement period with the final $2 \mathrm{~d}$ used for
\end{abstract}

Received August 9, 2017.

Accepted October 31, 2017.

${ }^{1}$ Corresponding author: bbradfor@ksu.edu data and sample collection, and an 8-d treatment period with the final $2 \mathrm{~d}$ used for data and sample collection. Plasma, urine, and milk samples were analyzed for L-carnitine. Crystalline and 40COAT linearly increased plasma L-carnitine, and 60COAT tended to linearly increase plasma L-carnitine. Total excretion (milk + urine) of L-carnitine averaged $1.52 \pm 0.04 \mathrm{~g} / \mathrm{d}$ in controls, increased linearly with crystalline and 40COAT, and increased quadratically with 60COAT. Crystalline increased plasma L-carnitine and L-carnitine excretion more than 40COAT and 60COAT. In conclusion, preventing ruminal degradation of L-carnitine increased delivery of bioavailable carnitine to cattle, but effective ruminal protection and postruminal bioavailability is challenging.

Key words: L-carnitine, bioavailability, dairy cow

\section{INTRODUCTION}

Fatty liver is a metabolic disease that occurs during the first few weeks of lactation and affects up to $50 \%$ of dairy cows (Grummer, 1993; Jorritsma et al., 2000). Dry matter intake declines around calving, resulting in rapid lipolysis of adipose tissue triacylglycerides (TAG) to provide an insulin-independent energy source for tissues and to support gluconeogenesis. Hepatic uptake of fatty acids often occurs in excess of its oxidation capacity with resultant re-esterification and storage of TAG (Vernon, 2005). Liver lipid accumulation damages hepatocytes, decreasing metabolic function of the liver, and fatty liver has been associated with decreased health status and reproductive performance (Wensing et al., 1997; Bobe et al., 2004). Key control points for hepatic lipid metabolism include delivery of fatty acids to the liver and transport into the mitochondria by carnitine palmitoyltransferase 1 (Drackley, 1999).

L-Carnitine plays an essential role in the transport of long-chain fatty acids (LCFA) from the cytosol into the mitochondria of hepatocytes (Longo et al., 2006). The conjugation of L-carnitine with LCFA by CPT1 in the outer mitochondrial membrane is considered the 
rate-limiting step in carnitine-dependent fatty acid oxidation (Louet et al., 2001). From 3 wk before calving to $1 \mathrm{wk}$ postpartum, the concentration of free carnitine decreased while acylcarnitine concentration increased; however, total postpartum carnitine concentration (free carnitine + carnitine esters) was decreased relative to prepartum values (Schlegel et al., 2012). Cows that rapidly mobilize body fat, grouped by postpartum liver lipid content, exhibited elevated concentrations of acylcarnitines and decreased free carnitine concentrations (Humer et al., 2016). Hepatic mRNA abundance of CPT1 was greatest around d 1 of lactation, coinciding with peak levels of plasma fatty acids (Ingvartsen and Anderson, 2000; Loor et al., 2005; Schlegel et al., 2012). Increased CPT1 mRNA expression was also observed in cows with greater BCS at calving (Akbar et al., 2015). Increased mRNA abundance of carnitine palmitoyltransferase 1 and decreased free hepatic carnitine concentrations suggest that exogenous carnitine supply could enhance transport and oxidation of LCFA in the postpartum period, particularly in cows with the greatest elevations in plasma fatty acid concentration.

In vitro incubation of liver slices from early lactation cows with L-carnitine increased $\beta$-oxidation of palmitate and decreased palmitate esterification (Drackley et al., 1991). Dietary administration of L-carnitine during the transition period was effective at increasing hepatic carnitine concentration, with a subsequent decrease in total liver lipid content at 10 DIM, the time of peak liver TAG concentration (Drackley et al., 2005; Carlson et al., 2007a).

Carnitine is degraded in the rumen, but the extent of degradation is unknown. Abomasal and ruminal infusions of carnitine $(6 \mathrm{~g} / \mathrm{d})$ were equally effective at increasing plasma carnitine concentrations in one study, suggesting some carnitine is able to escape ruminal degradation and be available for intestinal absorption (LaCount et al., 1995). Previous studies have assumed $80 \%$ ruminal degradation for lactating dairy cows fed a commercial carnitine supplement $(6,50$, and $100 \mathrm{~g} / \mathrm{d}$ of a 50\% L-carnitine product; Carlson et al., 2007a), and $25 \%$ absorption was speculated for growing steers supplemented at 2 and $3 \mathrm{~g}$ of carnitine per day (Greenwood et al., 2001).

More research is needed to determine the extent of ruminal carnitine degradation to evaluate the necessity for a rumen-protected form of L-carnitine. The objective of experiment 1 was to assess the relative bioavailability of L-carnitine when administered at different sites and different infusion rates, whereas experiment 2 assessed the relative bioavailability of 2 rumen-protected carnitine (RPC) products compared with crystalline carnitine. Experiment 2 also determined production responses to supplemental carnitine, including milk yield, milk components, and feed intake. We hypothesized that ruminal microbial degradation would reduce relative bioavailability of ruminally administered carnitine and that feeding rumen-protected products would result in greater relative carnitine bioavailability than crystalline carnitine. Relative change in plasma carnitine concentration was used to assess relative bioavailability.

\section{MATERIALS AND METHODS}

Experimental procedures were approved by the Kansas State University Institutional Animal Care and Use Committee (protocols 3300 and 3653).

\section{Experiment 1}

Four Holstein heifers previously fitted with ruminal cannulas were used in a split-plot design to assess the relative bioavailability of ruminally or abomasally administered L-carnitine. However, 1 heifer was removed just before the end of the first treatment period due to an intestinal blockage requiring surgery. A second heifer was removed due to an infection during phase 2 of period 2. At that time, the heifer removed in period 1 had recovered and was used to replace the second heifer for phase 3 of period 2. The study was therefore an incomplete design. Heifers were housed in a tiestall facility and fed a TMR once daily (Table 1). The diet met requirements for all nutrients (NRC, 2001).

The study was conducted in 2 periods, both preceded by 2 wk without treatment to obtain baseline samples and for washout between periods. Each period had 3 phases, each consisting of $4 \mathrm{~d}$ of infusions at a different dose of carnitine, with $4 \mathrm{~d}$ between phases. The treatments included ruminal infusion of 1,3 , and $6 \mathrm{~g}$ of L-carnitine/d and abomasal infusion of 1,3 , and 6 $\mathrm{g}$ of L-carnitine/d. Each carnitine treatment also included $6 \mathrm{~g} / \mathrm{d}$ of larch arabinogalactan in consideration of eventual product manufacturing, and was solubilized in water $(\mathrm{pH}=9.4)$ with the total volume infused being $4 \mathrm{~L} / \mathrm{d}$ across treatments. The dosage used in each phase escalated, with phase 1 at $1 \mathrm{~g} / \mathrm{d}$, phase 2 at 3 $\mathrm{g} / \mathrm{d}$, and phase 3 at $6 \mathrm{~g} / \mathrm{d}$, to minimize the relative effect of any carryover. Doses were based on the previous dose response study by LaCount et al. (1996a) in which plasma carnitine concentration appeared to be maximized at $6 \mathrm{~g}$ L-carnitine/d. The site of infusion was randomized; 2 heifers received ruminal infusions in period 1, followed by abomasal infusions in period 2 , and the other heifer was treated in the opposite sequence. Daily infusions (throughout each 4 -d infusion) were split into 2 equal aliquots, each infused during 10-h infusion periods, allowing $2 \mathrm{~h}$ between infusions. 
The settings of the peristaltic pump (Harvard Apparatus, Holliston, MA) to achieve the desired infusion flow rate were predetermined in the laboratory and adjusted as needed during the experiment to ensure that the total volume was infused. Retention of lines in the abomasum was verified upon removal.

Throughout the study, feed and water intake was recorded daily with the final $3 \mathrm{~d}$ of each infusion phase used for analysis. Samples of TMR were collected every 2 wk and composited for near-infrared nutrient analysis by Dairy One Forage Laboratory (Ithaca, NY; Table 1). Health was monitored daily.

Prior to the start of infusions and $1.5 \mathrm{~h}$ following the first daily infusion on $\mathrm{d} 4$ of each phase, blood samples (coccygeal vein) were used to obtain baseline and treatment carnitine concentrations. Blood was collected into vacutainer tubes containing $\mathrm{K}_{3}$ EDTA and immediately placed on ice. Plasma was separated by centrifugation $\left(3,000 \times g\right.$ for $15 \mathrm{~min}$ at $\left.20^{\circ} \mathrm{C}\right)$ and frozen until carnitine analysis.

\section{Experiment 2}

Cows and Treatments. Fifty-six mid-lactation Holstein cows (143 \pm 72 DIM) were used in a randomized complete block design to determine the relative bioavailability of $2 \mathrm{RPC}$ products compared with crystalline carnitine. Cows were blocked by parity and level of milk production and then randomly assigned to 1 of 7 treatments within block $(\mathrm{n}=8)$. Using variance data from LaCount et al. (1995), power analysis determined that this design provided sufficient power $(\alpha=0.05, \beta$ $=0.80)$ to detect a change in urinary carnitine excretion of $0.36 \mathrm{~g} / \mathrm{d}$. Cows were housed in a tiestall facility and adapted to the facility for $4 \mathrm{~d}$ before $2 \mathrm{~d}$ of sample collection for baseline values. Following the 6 - $\mathrm{d}$ baseline period, treatments were applied for a total of $8 \mathrm{~d}$, with the final $2 \mathrm{~d}$ used for data and sample collection. The 2-d collection period provided sufficient time for collection of 6 milk samples and 4 urine and blood samples to minimize random variance due to sampling time, while also allowing us to assess diurnal variation in blood concentrations. The study was performed in 2 cohorts of 28 cows each.

Cows were milked 3 times daily at 0400, 1000, and $1800 \mathrm{~h}$. The basal diet (Table 2) met requirements for all nutrients (NRC, 2001) and was fed as a TMR twice daily (0600 and $1800 \mathrm{~h}$ ). Cows had ad libitum access to feed in individual mangers, and feed offered was adjusted daily to achieve 12 to $20 \%$ refusals. During the treatment period, the basal diet was top-dressed twice daily with the following treatments: (a) control (no supplement), (b) $3 \mathrm{~g} / \mathrm{d}$ of crystalline L-carnitine (crystalline; Lonza Inc., Allendale, NJ), (c) $6 \mathrm{~g} / \mathrm{d}$ of crystalline, (d) $5 \mathrm{~g} / \mathrm{d}$ of 40COAT (40\% coating, $60 \%$ L-carnitine; Lonza Inc.), (e) $10 \mathrm{~g} / \mathrm{d}$ of 40COAT, (f) $7.5 \mathrm{~g} / \mathrm{d}$ of 60COAT $(60 \%$ coating, $40 \%$ L-carnitine coating; Lonza Inc.), and (g) $15 \mathrm{~g} / \mathrm{d}$ of 60COAT. The encapsulated carnitine doses correspond to a total of 3 and $6 \mathrm{~g}$ of total carnitine, respectively. Thus, the doses correspond with experiment 1 , which were according to results from LaCount et al. (1996a). Treatments were mixed in the top third of the ration offered.

Data Collection and Sampling Procedures. During the 2-d collection periods, feed and water intake as well as milk yield were recorded. Total mixed ration samples were collected on each day of both baseline and treatment collection periods and composited for nutrient analysis by Dairy One Forage Laboratory (Table 2 ). Health was monitored daily, and one cow $(7.5 \mathrm{~g}$ of 60COAT) was removed from the study due to illness detected by a rapid decline in DMI.

Over the course of the 48-h collection period, urine and blood samples (coccygeal vein) were collected immediately before feeding (2000 h on d 5 and 13), and 6,12 , and $18 \mathrm{~h}$ after. Blood samples were collected into $\mathrm{K}_{3}$ EDTA tubes and immediately placed on ice. Plasma was separated by centrifugation $(3,000 \times g$ for $15 \mathrm{~min}$

Table 1. Ingredient and nutritional composition of the basal diet (experiment 1)

\begin{tabular}{lc}
\hline Item & Concentration \\
\hline Ingredient, \% of DM & \\
Alfalfa hay & 21.0 \\
Grass hay & 1.7 \\
Corn silage & 16.1 \\
Wet corn gluten feed $^{1}$ & 25.7 \\
Cottonseed & 4.4 \\
Fine rolled corn & 20.4 \\
Micronutrient premix & \\
Nutrient, \% of DM (unless otherwise specified) & 10.7 \\
DM, \% asfed & \\
CP & 53.5 \\
Soluble protein, \% CP & 17.9 \\
ADF & 40.5 \\
NDF & 24.75 \\
Lignin & 43.8 \\
NFC & 4.55 \\
Starch & 26.75 \\
Ether extract & 17.9 \\
ISwet Bran Cargill & 4.75 \\
\hline
\end{tabular}

${ }^{1}$ Sweet Bran (Cargill Inc., Blair, NE).

${ }^{2}$ Premix consisted of $58.6 \%$ expeller soybean meal (SoyBest, Grain States Soya, West Point, NE), $11.7 \%$ limestone, $10.3 \%$ sodium bicarbonate, $7.32 \%$ Ca salts of long-chain fatty acids (Megalac R, Arm \& Hammer Animal Nutrition, Princeton, NJ), 2.34\% magnesium oxide, $1.83 \%$ XP Yeast (Diamond V, Cedar Rapids, IA), 1.46\% stock salt, $1.46 \%$ trace mineral salt, $1.46 \%$ potassium chloride, $1.46 \%$ vitamin E premix (48 kIU/g), 0.91\% Biotin 100 (ADM Alliance Nutrition, Quincy, IL), $0.62 \%$ NiaShure (65\% niacin, Balchem Corp., New Hampton, NY), $0.25 \%$ selenium premix $(0.06 \%), 0.23 \%$ 4-Plex (Zinpro Corp., Eden Prairie, MN), 0.15\% vitamin A premix (30 kIU/g), 0.12\% Zinpro 100 (Zinpro Corp.), 0.06\% Rumensin 90 (Elanco Animal Health, Greenfield, IN), 0.04\% vitamin D premix (30 kIU/g), 0.01\% ethylenediamine dihydriodide premix $(3.65 \% \mathrm{I})$. 
at $20^{\circ} \mathrm{C}$ ) and stored in microcentrifuge tubes at $-20^{\circ} \mathrm{C}$. Throughout the collection period, urine samples $(200$ $\mu \mathrm{L}$ ) were composited within cow by equal volumes into microcentrifuge tubes and frozen at $-20^{\circ} \mathrm{C}$ until analysis of total carnitine and creatinine. Two milk samples were collected at all 6 milkings during the 2 -d collection periods; one was used for milk component analysis and the other was frozen until carnitine analysis. Prior to analyses, the milk samples were composited in equal volumes by collection period.

\section{Sample Analyses}

Milk samples were analyzed for concentrations of fat, true protein, lactose (B-2000 Infrared Analyzer; Bentley Instruments, Chaska, MN), MUN (MUN spectrophotometer, Bentley Instruments), and somatic cells (SCC 500, Bentley Instruments) by Heart of America DHIA (Manhattan, KS). Plasma was analyzed using enzymatic colorimetric assays to determine concentrations of fatty acids (NEFA-HR; Wako Chemicals, Richmond, VA) and BHB (kit no. H7587-58, Pointe Scientific, Canton, MI). Urine creatinine concentration

Table 2. Ingredient and nutritional composition of the basal diet (experiment 2)

\begin{tabular}{|c|c|c|}
\hline Item & Concentration & $\mathrm{SD}$ \\
\hline \multicolumn{3}{|l|}{ Ingredient, $\%$ of DM } \\
\hline Corn silage & 35.0 & \\
\hline Alfalfa hay & 14.2 & \\
\hline Wet corn gluten feed ${ }^{1}$ & 27.3 & \\
\hline Cottonseed & 2.7 & \\
\hline Fine-rolled corn & 13.7 & \\
\hline Micronutrient premix ${ }^{2}$ & 7.0 & \\
\hline \multicolumn{3}{|c|}{$\begin{array}{l}\text { Nutrient, \% of DM } \\
\text { (unless otherwise specified) }\end{array}$} \\
\hline DM, \% asfed & 49.9 & 0.91 \\
\hline $\mathrm{CP}$ & 17.5 & 0.34 \\
\hline Soluble protein, \% CP & 36.3 & 3.59 \\
\hline $\mathrm{ADF}$ & 23.3 & 1.14 \\
\hline NDF & 36.3 & 1.48 \\
\hline Lignin & 4.1 & 0.22 \\
\hline NFC & 33.0 & 1.42 \\
\hline Starch & 16.2 & 1.17 \\
\hline Ether extract & 4.9 & 0.18 \\
\hline $\mathrm{NE}_{\mathrm{L}},{ }^{3} \mathrm{Mcal} / \mathrm{kg}$ & 1.65 & 0.01 \\
\hline \multicolumn{3}{|c|}{${ }^{1}$ Sweet Bran (Cargill Inc., Blair, NE). } \\
\hline \multicolumn{3}{|c|}{$\begin{array}{l}{ }^{2} \text { Premix consisted of } 54.6 \% \text { expeller soybean meal (SoyBest, Grain } \\
\text { States Soya, West Point, NE), } 14.8 \% \text { limestone, } 10.9 \% \text { sodium bi- } \\
\text { carbonate, } 7.8 \% \text { Ca salts of long-chain fatty acids (Megalac R, Arm } \\
\text { \& Hammer Animal Nutrition, Princeton, NJ), } 2.49 \% \text { magnesium ox- } \\
\text { ide, } 2.34 \% \text { stock salt, } 1.95 \% \text { XP Yeast (Diamond V, Cedar Rapids, } \\
\text { IA), } 1.56 \% \text { trace mineral salt, } 1.56 \% \text { vitamin E premix ( } 48 \mathrm{kIU} / \mathrm{g} \text { ), } \\
0.97 \% \text { Biotin } 100 \text { (ADM Alliance Nutrition, Quincy, IL), } 0.26 \% \text { se- } \\
\text { lenium premix (0.06\%), 0.24\% 4-Plex (Zinpro Corp., Eden Prairie, } \\
\text { MN), 0.16\% potassium chloride, } 0.16 \% \text { vitamin A premix ( } 30 \mathrm{kIU} / \mathrm{g} \text { ), } \\
0.12 \% \text { Zinpro } 100 \text { (Zinpro Corp.), } 0.07 \% \text { Rumensin } 90 \text { (Elanco Animal } \\
\text { Health, Greenfield, IN), 0.05\% vitamin D premix (30 kIU/g), } 0.01 \% \\
\text { ethylenediamine dihydriodide premix (3.65\% I). } \\
{ }^{3} \text { Estimated according to NRC (2001). }\end{array}$} \\
\hline
\end{tabular}

and expected excretion of creatinine at $29 \mathrm{mg} / \mathrm{kg}$ of BW per day were used to estimate daily urine volume (Valadares et al., 1999).

Concentrations of total carnitine in plasma, milk, and urine were determined by an enzymatic radioisotope method (Carlson et al., 2007b). Plasma (0.5 $\mathrm{mL})$, milk $(1.0 \mathrm{~mL})$, and urine $(1.0 \mathrm{~mL})$ samples were alkalinized with 25,50 , and $60 \mu \mathrm{L}$ of $3 \mathrm{M} \mathrm{KOH}$, respectively. To prevent gelling in subsequent steps, $250 \mu \mathrm{L}$ of water was added to plasma samples. Samples were mixed and incubated in a water bath at $60^{\circ} \mathrm{C}$ for $1 \mathrm{~h}$. Samples were deproteinized by adding of $150 \mu \mathrm{L}$ of 3 $M \mathrm{HClO}_{4}$ to plasma samples and $300 \mu \mathrm{L}$ to urine and milk samples, mixing, and placing samples on ice for $10 \mathrm{~min}$. After centrifugation at $10,000 \times g$ for $10 \mathrm{~min}$, $500 \mu \mathrm{L}$ of supernatant was transferred to a separate 1.5-mL microcentrifuge tube and neutralized with 73 $\mu \mathrm{L}$ of $3 \mathrm{M} \mathrm{KOH}$ for plasma and urine samples and 105 $\mu \mathrm{L}$ for milk samples. After incubation on ice for $10 \mathrm{~min}$, samples were centrifuged for $10 \mathrm{~min}$ at $10,000 \times \mathrm{g}$. The supernatant was transferred to a clean microcentrifuge tube and frozen until analysis.

To quantify carnitine concentrations, $50 \mu \mathrm{L}$ of supernatant, standard, or blank was pipetted into $12 \times 75$ $\mathrm{mm}$ borosilicate tubes in duplicate. Volumes of $0.75 \mathrm{~mL}$ ${ }^{14} \mathrm{C}$-acetyl-CoA reaction mix $\left(0.3 \mu \mathrm{Ci}{ }^{14} \mathrm{C}\right.$-acetyl-CoA, Moravek Biochemicals, Brea, CA), $0.75 \mathrm{~mL}$ of HEPESEDTA buffer (pH 7.6), $1 \mu \mathrm{L}$ of acetyl-CoA stock (21 $\mathrm{mg}$ of acetyl-CoA in $1 \mathrm{~mL}$ of deionized water), and $0.25 \mathrm{mg}$ of $\mathrm{N}$-ethylmaleimide (Sigma-Aldrich, St. Louis, MO) were added to each assay tube. A volume of $20 \mu \mathrm{L}$ of carnitine acyltransferase enzyme (Roche Diagnostics Corp., Indianapolis, IN) was added to all tubes (except blanks) at 5- to 10-s intervals to better equalize incubation times in subsequent steps, and vortexed. After incubation for $30 \mathrm{~min}$ in a $37^{\circ} \mathrm{C}$ water bath, $0.5 \mathrm{~mL}$ from each reaction was pipetted onto a ion-exchange column (Dowex $1 \times 8$ 100-200 ION-Exchange Resin; SigmaAldrich), draining directly into a scintillation vial. Columns were rinsed 4 times with $0.5 \mathrm{~mL}$ of deionized water, allowing each aliquot to run through completely before next addition. Scintillation cocktail $(10 \mathrm{~mL}$, ScintiSafe 30\%, Fisher Scientific, Pittsburgh, PA) was added to each vial to count ${ }^{14} \mathrm{C}$. Unknowns were quantified using a standard curve, with the sample blank subtracted before applying the regression equation. Intraassay coefficients of variation for plasma, urine, and milk were $4.76,2.20$, and $1.76 \%$, respectively.

\section{Statistical Analyses}

In experiment 1 , there were 3 observations for all dose $\times$ route combinations, except the $3 \mathrm{~g} / \mathrm{d}$ abomasally infused carnitine, for which there were 2. Carnitine 
Table 3. Effect of ruminal or abomasal infusion of carnitine on intake and plasma carnitine concentration of Holstein heifers (experiment 1)

\begin{tabular}{|c|c|c|c|c|c|c|c|c|c|c|}
\hline \multirow[b]{2}{*}{ Item } & \multicolumn{3}{|c|}{ Ruminal infusion } & \multicolumn{3}{|c|}{ Abomasal infusion } & \multirow[b]{2}{*}{$\mathrm{SEM}^{1}$} & \multicolumn{3}{|c|}{$P$-value } \\
\hline & $1 \mathrm{~g}$ & $3 \mathrm{~g}$ & $6 \mathrm{~g}$ & $1 \mathrm{~g}$ & $3 \mathrm{~g}$ & $6 \mathrm{~g}$ & & Dose & Route & Dose $\times$ route \\
\hline DMI, $\mathrm{kg} / \mathrm{d}$ & 18.0 & 18.8 & 18.9 & 16.8 & 19.0 & 17.4 & 1.0 & 0.07 & 0.13 & 0.35 \\
\hline Water intake, L/d & 7.7 & 8.0 & 8.6 & 8.3 & 9.2 & 7.9 & 0.7 & 0.66 & 0.58 & 0.41 \\
\hline Baseline plasma carnitine, $\mu M$ & 13.5 & 12.4 & 13.1 & 14.7 & 13.6 & 16.5 & 1.5 & 0.27 & 0.06 & 0.51 \\
\hline Change in plasma carnitine, ${ }^{2} \mu M$ & -0.6 & 12.3 & 9.0 & 4.5 & 20.5 & 35.9 & 4.8 & 0.099 & $<0.01$ & 0.045 \\
\hline
\end{tabular}

${ }^{1}$ Reported SEM is pooled across route and dose levels.

${ }^{2}$ Plasma concentrations reported are the difference between baseline and treatment concentrations.

concentration was expressed as the difference between pre- and postinfusion values. Statistical analysis was performed using JMP (version 12, SAS Institute Inc., Cary, NC). Dependent variables (feed intake, water intake, change in plasma carnitine concentration) were analyzed to determine the fixed effects of route of administration, dose of carnitine, and their interaction, along with the random effects of heifer and phase within period. Contrast statements were used to statistically test linear regression coefficients with increasing doses for ruminal versus abomasal infusions. To assess relative bioavailability, least squares means were regressed against dose for the 2 infusion routes with the intercept forced through the origin.

In experiment 2, statistical analysis was performed using SAS (version 9.3, SAS Institute Inc.). The mixed procedure was used to model treatment response variables using the covariate for the same variable from the basal period, the fixed effects of treatment and parity, and the random effect of block. Responses were assessed with 9 contrasts that assessed the linear and quadratic responses to crystalline, 40COAT, and 60COAT treatments as well as overall contrasts between crystalline and 40COAT, crystalline and 60COAT, and 40COAT versus 60COAT treatments. To achieve a normal distribution of residuals, somatic cell linear score (SCLS) was calculated as described by Schukken et al. (2003): SCLS $=\log _{2}(\mathrm{SCC} / 100)+3$. Significance in experiments 1 and 2 was declared at $P<0.05$ and tendencies were declared at $0.05 \leq P<0.10$.

\section{RESULTS AND DISCUSSION}

\section{Experiment 1}

Feed and Water Intake. Water intake was not affected by carnitine infusion across dose or route (all $P>0.40$; Table 3). Although not affected by route $(P=0.13)$, DMI tended to increase quadratically with carnitine dose $(P=0.07)$, being greatest for the $3 \mathrm{~g} / \mathrm{d}$ of carnitine. LaCount et al. (1995) conducted a similar study in which water or $6 \mathrm{~g} / \mathrm{d}$ of carnitine was infused abomasally or ruminally in multiparous Holstein cows. Water intake was not reported, but no difference in DMI was observed for treatment or infusion site. Additionally, no effects on DMI were observed when carnitine was abomasally infused at $0,3,6$, or $12 \mathrm{~g} / \mathrm{d}$ (LaCount et al., 1996b) or $20 \mathrm{~g} / \mathrm{d}$ (Carlson et al., 2006). Currently we have no explanation for the tendency of carnitine dose to affect DMI; this effect should be interpreted cautiously, as our study had a small sample size and previous carnitine infusion studies reported no differences in DMI.

Plasma Carnitine Response. Plasma carnitine response to ruminal or abomasal carnitine infusion is reported as the difference between baseline and treatment concentrations in Table 3. An analysis of baseline concentration demonstrated that baseline carnitine was not affected by escalating dose $(P=0.27)$, but was different among individual heifers $(P=0.02)$. A dose $\times$ route interaction was observed $(P=0.045)$, which can largely be attributed to the linear increase in plasma carnitine concentrations with increasing abomasal infusion doses, without a significant effect for ruminal infusions. A route effect was observed $(P=0.005)$ with carnitine being more bioavailable across all dose levels when infused abomasally compared with ruminally.

To further characterize the relative bioavailability of carnitine via these 2 routes of administration, a doseresponse analysis was conducted (Figure 1). It should be noted that this assumes that increases in plasma concentration are directly related to the amount of carnitine absorbed and does not account for possible changes in carnitine flux from or to other pools (muscle, liver, urine, and so on). This assessment demonstrated that the relative bioavailability of carnitine is greater when supplied to the abomasum versus the rumen. Contrary to the route differences we observed, LaCount et al. (1995) reported similar increases in plasma carnitine concentration relative to control when carnitine $(6 \mathrm{~g} / \mathrm{d})$ was infused ruminally or abomasally. Plausible explanations for the discrepancy between studies include differences in physiological state (heifers vs. lactating cows), DMI and passage rate, duration of 


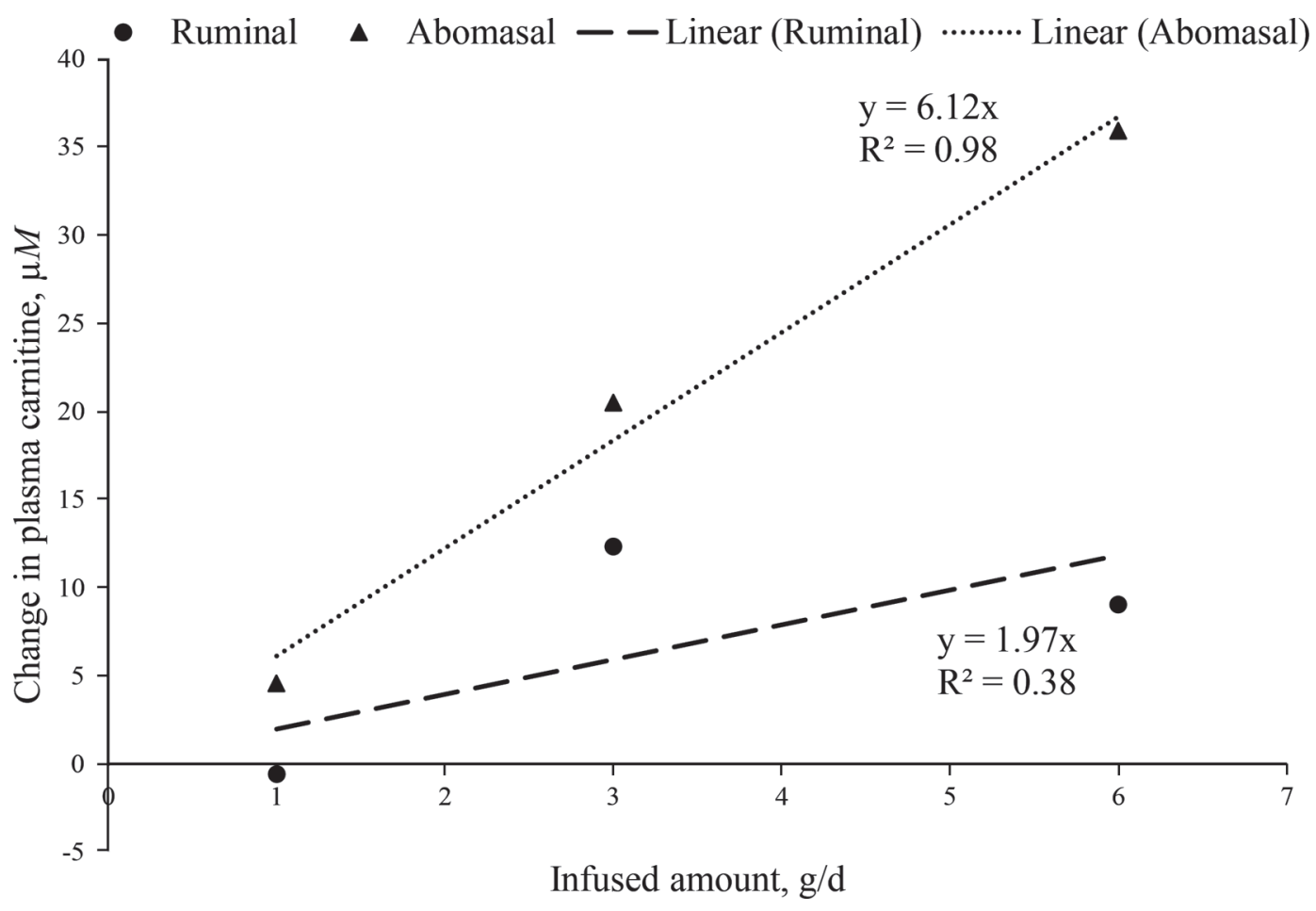

Figure 1. Marginal plasma carnitine responses to carnitine infusion differ by infusion route (experiment 1). Differences in plasma carnitine concentrations (postinfusion minus preinfusion concentrations) are plotted against infusion amount. The slopes differ between infusion routes ( $P$ $=0.02$ ), reflecting greater apparent bioavailability for abomasally delivered carnitine compared with ruminal infusion.

carnitine supplementation ( 4 vs. 21 d), and the method of ruminal carnitine infusion (continuous ruminal infusion vs. gelatin capsule containing carnitine placed in the rumen).

The numerically decreased carnitine concentration in response to $1 \mathrm{~g} / \mathrm{d}$ of ruminally infused carnitine was unexpected; however, given the small sample size of our study $(\mathrm{n}=3)$, that value was largely influenced by the response of 1 heifer. In the work of LaCount et al. (1995), ruminal infusion of $1 \mathrm{~g} / \mathrm{d}$ did not change plasma carnitine concentrations, and a 4 to $5 \%$ increase only occurred when 0.875 or $1.75 \mathrm{~g}$ of L-carnitine/d was topdressed on the diets of mid-lactation cows (LaCount et al., 1996b). The increase in plasma carnitine concentration was linear, demonstrating at least some bioavailability of greater doses $(3.5$ and $7 \mathrm{~g} / \mathrm{d}$; LaCount et al., 1996b). In our study plasma carnitine concentration was increased relative to baseline for 3 and 6 $\mathrm{g} / \mathrm{d}$ ruminally infused carnitine. The lack of difference between these 2 doses could have been affected by the sequence of treatments, given that adaptation of ruminal microbes may enhance carnitine degradation after a longer period of exposure (LaCount et al., 1996b). In adult humans, fractional degradation increases and the proportion of carnitine absorbed decreases as the amount of carnitine ingested increases (Rebouche,
1991). Harmeyer and Sporleder (2003) suggested that carnitine is not absorbed across the rumen wall, because exposing washed, empty rumens to high concentrations of carnitine (10 times blood concentrations) for $3 \mathrm{~h}$ did not result in a decrease in carnitine concentration in the ruminal media or an increase in plasma carnitine concentration. Therefore, transport of carnitine across the rumen epithelium at $6 \mathrm{~g} / \mathrm{d}$ is unlikely (Carlson et al., 2007a).

Our observed linear increase in plasma carnitine concentration in response to abomasal infusion aligns with the linear increase observed when 3,6 , or $12 \mathrm{~g} / \mathrm{d}$ carnitine was abomasally infused in mid-lactation cows (LaCount et al., 1996a). Although plasma concentrations were similar for 6 and $12 \mathrm{~g} / \mathrm{d}$ (64.8 vs. $67.5 \pm$ $5.4 \mu M$, respectively), urine carnitine concentration increased by 8 -fold relative to control at $12 \mathrm{~g} / \mathrm{d}$ compared with 4-fold at $6 \mathrm{~g} / \mathrm{d}$ (LaCount et al., 1996a). The similar increase in plasma carnitine concentration by dietary administration of 50 or $100 \mathrm{~g} / \mathrm{d}$ commercial carnitine supplement (50\% L-carnitine) also suggests potential saturation of intestinal absorption or renal reabsorption capacity at the highest dose (Carlson et al., 2007a).

Oral bioavailability of carnitine in humans was $16 \%$ at $2 \mathrm{~g} / \mathrm{d}$ and $5 \%$ at $6 \mathrm{~g} / \mathrm{d}$ (Harper et al., 1988), suggest- 
ing that these doses may exceed intestinal absorptive capacity for carnitine in humans. At a comparable dose relative to BW, $25 \%$ of a labeled carnitine dose was lost in feces in humans, compared with only $7 \%$ fecal loss in rats (Rebouche and Chenard, 1991). Other studies also suggest that the capacity for carnitine uptake is greater in nonhuman species. For example, in broiler studies, the net fractional absorption of L-carnitine for common feeding rates $(0-100 \mathrm{mg} / \mathrm{kg}$ ) was 82 to $96 \%$ (Mehlhorn, 2006). One confounding factor for many human studies is the frequency of supplementation. Single oral or intravenous doses of carnitine have little effect on the total carnitine pool, whereas repeated carnitine supplementation is more effective at maintaining circulating carnitine concentrations above baseline (Rebouche, 2004). It is hypothesized that dietary supplementation of carnitine, consumed in multiple meals daily, may result in superior bioavailability for production animals compared with the findings in human studies employing relatively large daily bolus doses. Considering that doses we investigated appear to be below the threshold suggested by the literature for dairy cattle, it is unlikely that saturation of ruminal or intestinal absorption limited relative bioavailability of carnitine at either site.

\section{Experiment 2}

Feed Intake and Milk Production. Production responses to dietary administration of crystalline carnitine, 40COAT, or 60COAT are summarized in Table 4. A quadratic effect on water intake was observed with 40COAT, but water intake was not affected by other treatments. The 60COAT product linearly decreased DMI $(P=0.02)$ and crystalline tended to linearly decrease DMI $(P=0.07)$. Dietary carnitine supplementation at doses ranging from 0 to $7 \mathrm{~g} / \mathrm{d}$ during late lactation did not reduce DMI (LaCount et al., 1996a), but dietary supplementation of a $50 \%$ L-carnitine product at $100 \mathrm{~g} / \mathrm{d}$ during the periparturient period reduced intake for the first 2 wk of lactation (Carlson et al., 2007a). We have previously speculated that supplemental carnitine may suppress DMI by enhancing fatty acid oxidation, leading to increased mean hepatic ATP concentrations and delayed hunger via vagal nerve signaling to the hypothalamus (Allen et al., 2009). However, our discussion of this mechanism focused on periparturient dairy cows, where lipid flux to the liver is greatly elevated compared with the cohort in this study. Neither crystalline nor RPC fed to feedlot lambs (White et al., 2002; Solhjoo et al., 2014) or RPC administered to mid-lactation dairy cows (Tasdemir et al., 2011) affected DMI. Responses in the 2 studies reported herein were of limited magnitude and were in opposite directions, with a tendency for increased DMI in heifers infused with $3 \mathrm{~g} / \mathrm{d}$ of L-carnitine (experiment 1) and linearly decreased DMI in lactating cows fed L-carnitine as 60COAT. Carnitine effects on DMI are likely inconsistent because of interactions with the metabolic state of the animal.

Dietary carnitine supplementation had no effect on milk yield or yields of milk fat, protein, and lactose. Although crystalline carnitine supplementation by either feeding or infusion did not alter milk yield in most studies (LaCount et al., 1995, 1996a,b; Carlson et al.,

Table 4. Effect of carnitine supplementation on performance and milk production parameters of mid-lactation Holstein cows fed different amounts and sources of L-carnitine (experiment 2)

\begin{tabular}{|c|c|c|c|c|c|c|c|c|}
\hline \multirow[b]{2}{*}{ Item } & \multirow[b]{2}{*}{ Control } & \multicolumn{2}{|c|}{ Crystalline } & \multicolumn{2}{|c|}{$40 \mathrm{COAT}^{1}$} & \multicolumn{2}{|c|}{$60 \mathrm{COAT}^{1}$} & \multirow[b]{2}{*}{$\mathrm{SEM}^{2}$} \\
\hline & & $3 \mathrm{~g}$ & $6 \mathrm{~g}$ & $5 \mathrm{~g}$ & $10 \mathrm{~g}$ & $7.5 \mathrm{~g}$ & $15 \mathrm{~g}$ & \\
\hline Milk, kg/d & 44.8 & 45.0 & 44.7 & 44.7 & 45.1 & 43.0 & 44.2 & 1.1 \\
\hline Milk fat, ${ }^{5} \%$ & 3.66 & 3.53 & 3.47 & 3.50 & 3.47 & 3.31 & 3.48 & 0.11 \\
\hline Milk protein, ${ }^{6} \%$ & 2.86 & 2.91 & 2.84 & 2.90 & 2.88 & 2.86 & 2.85 & 0.04 \\
\hline MUN, mg/dL & 13.34 & 13.41 & 13.33 & 13.04 & 13.10 & 13.10 & 13.35 & 0.30 \\
\hline Milk fat, $\mathrm{kg} / \mathrm{d}$ & 1.64 & 1.55 & 1.56 & 1.59 & 1.52 & 1.43 & 1.55 & 0.07 \\
\hline Milk protein, $\mathrm{kg} / \mathrm{d}$ & 1.28 & 1.31 & 1.26 & 1.30 & 1.30 & 1.23 & 1.26 & 0.04 \\
\hline Milk lactose, $\mathrm{kg} / \mathrm{d}$ & 2.20 & 2.22 & 2.20 & 2.20 & 2.20 & 2.12 & 2.19 & 0.06 \\
\hline
\end{tabular}

${ }^{1} 40 \mathrm{COAT}=40 \%$ coating rumen-protected L-carnitine product; $60 \mathrm{COAT}=60 \%$ coating rumen-protected L-carnitine product.

${ }^{2}$ Reported SEM is pooled across treatment groups.

${ }^{3}$ Linear effect of $60 \%$ coating product.

${ }^{4}$ Quadratic effect of $40 \%$ coating product.

${ }^{5}$ Quadratic effect of $60 \%$ coating product.

${ }^{6}$ Quadratic effect of crystalline carnitine.

${ }^{7}$ Somatic cell linear score $=\log _{2}(\mathrm{SCC} / 100)+3$. 
2006), Tasdemir et al. (2011) reported a 5\% decrease in milk yield in mid-lactation cows fed RPC. However, interpretation of those results is hindered by small sample size $(\mathrm{n}=8)$ and low production animals (19.6 $\mathrm{kg}$ of milk/d). Dietary administration of a high dose $(100 \mathrm{~g} / \mathrm{d})$ of a carnitine product (50\% L-carnitine) during the periparturient period resulted in a $22 \%$ decrease in milk yield compared with control, but the decrease corresponded to reduced DMI (Carlson et al., 2007a).

Crystalline carnitine had a quadratic effect on milk protein concentration $(P=0.04)$, with the intermediate dose resulting in the greatest milk protein concentration. The 60COAT product tended to decrease milk protein content $(P=0.10)$ and increase milk lactose content $(P=0.08)$ compared with 40COAT. High dose $(100 \mathrm{~g} / \mathrm{d})$ carnitine tended to increase milk protein concentration relative to a lesser dose $(50 \mathrm{~g} / \mathrm{d}$; Carlson et al., 2007a), but carnitine supplementation has otherwise not significantly affected milk protein concentration or yield (LaCount et al., 1995, 1996a,b; Tasdemir et al., 2011). A quadratic effect on milk fat concentration was observed for 60COAT $(P=0.04)$; milk fat concentration was decreased at both doses relative to control. Feeding carnitine at increasing doses $(0.875$ to $7 \mathrm{~g} / \mathrm{d})$ tended to decrease milk fat yield and decreased yield of TS, resulting in the tendency for decreased FCM yield (LaCount et al., 1996b). Interestingly, milk fat yield and FCM yield were less in cows abomasally infused compared with ruminally infused with carnitine, and SNF concentration was increased for carnitine-infused cows compared with control (LaCount et al., 1995). Discrepancies in milk yield and composition response could be attributed to differences in carnitine source, dose, and protection, as well as stage of lactation and production level of the cows.

Metabolic Parameters. No treatment effects were observed for plasma fatty acid or BHB concentrations (all $P>0.15$; Table 5). Our results are in agreement with previous research in which carnitine administration via the rumen or abomasum to mid- or late-lactation cows did not alter fatty acid or BHB concentrations (LaCount et al., 1995, 1996a,b). Considering net lipid mobilization is typically minimal during mid-lactation, it is not surprising that effects on fatty acids and BHB were not observed. However, carnitine supplementation also failed to influence plasma fatty acid concentrations during feed restriction or early lactation, situations in which fatty acid mobilization is increased (Carlson et al., 2006, 2007b). Supplementation of $10 \mathrm{~g} / \mathrm{d}$ of a RPC product (supplying $2 \mathrm{~g} / \mathrm{d}$ of carnitine) from $21 \mathrm{~d}$ before calving through 60 DIM decreased blood fatty acid concentration in multiparous cows in the week before parturition, but had no effect on BHB concentration (Scholz et al., 2014). Intravenous infusion of L-carnitine did not affect plasma BHB concentration in healthy mid-lactation cows; however, carnitine did decrease plasma BHB and fatty acid concentrations in cows with spontaneous ketosis and feed restriction induced negative energy balance (Erfle et al., 1971). Supplementation of carnitine to growing calves linearly decreased prefeeding plasma fatty acid concentration, but linearly increased fatty acids $6 \mathrm{~h}$ after feeding (Greenwood et al., 2001). The response suggests additional carnitine allowed for greater oxidation of mobilized fatty acids in the fasted state, but opposite effects during the fed state. In that study, plasma BHB concentration was not affected by carnitine supplementation, suggesting incomplete oxidation of fatty acids was not influenced by increased fatty acid concentrations (Greenwood et al., 2001).

Plasma Carnitine Response. Plasma, urine, and milk carnitine concentrations were used to evaluate 2 rumen-protected products (40COAT and 60COAT) compared with crystalline carnitine (Table 6). Although there were no parity effects on baseline-adjusted plasma, milk, or urine carnitine concentrations, and only a tendency for a parity effect on total daily carnitine excretion $(P=0.10)$, baseline plasma carnitine concentrations were greater $(P<0.001)$ in primiparous compared with multiparous cows (9.40 vs. $5.87 \pm 0.25$ $\mu M)$. Plasma samples were collected at $0,6,12$, and 18 $\mathrm{h}$ after feeding to assess diurnal variation; however, no effect was observed of time on plasma carnitine concentrations $(P=0.23)$. Supplementation with crystalline

Table 5. Blood metabolite concentrations from mid-lactation Holstein cows fed difference amounts and sources of L-carnitine

\begin{tabular}{|c|c|c|c|c|c|c|c|c|}
\hline \multirow[b]{2}{*}{ Item } & \multirow[b]{2}{*}{ Control } & \multicolumn{2}{|c|}{ Crystalline } & \multicolumn{2}{|c|}{ 40COAT } & \multicolumn{2}{|c|}{$60 \mathrm{COAT}$} & \multirow[b]{2}{*}{$\mathrm{SEM}^{2}$} \\
\hline & & $3 \mathrm{~g}$ & $6 \mathrm{~g}$ & $5 \mathrm{~g}$ & $10 \mathrm{~g}$ & $7.5 \mathrm{~g}$ & $15 \mathrm{~g}$ & \\
\hline Fatty acids, $\mu M$ & 95 & 105 & 98 & 103 & 98 & 101 & 100 & 6.2 \\
\hline $\mathrm{BHB}, \mu M$ & 802 & 793 & 772 & 816 & 779 & 811 & 813 & 41.5 \\
\hline
\end{tabular}


Table 6. Least squares means for concentrations of L-carnitine in plasma, milk, and urine from mid-lactation Holstein cows fed different amounts and sources of L-carnitine (experiment 2)*

\begin{tabular}{|c|c|c|c|c|c|c|c|c|}
\hline Item & Control & \multicolumn{2}{|c|}{ Crystalline } & \multicolumn{2}{|c|}{ 40COAT } & \multicolumn{2}{|c|}{ 60COAT } & SEM \\
\hline $\begin{array}{l}\text { Plasma, }{ }^{2,3,4,5} \mu M \\
\text { Milk }\end{array}$ & 8.59 & 9.80 & 12.17 & 9.36 & 10.46 & 8.62 & 9.77 & 0.47 \\
\hline $\begin{array}{l}\mu M^{2,3,5,6} \\
\mathrm{~g} / \mathrm{d}^{2,3,5,6}\end{array}$ & $\begin{array}{c}137.5 \\
0.97\end{array}$ & $\begin{array}{r}166.4 \\
1.17\end{array}$ & $\begin{array}{r}174.3 \\
\quad 1.22\end{array}$ & $\begin{array}{r}145.6 \\
1.05\end{array}$ & $\begin{aligned} & 176.1 \\
& 1.22\end{aligned}$ & $\begin{array}{r}143.2 \\
0.99\end{array}$ & $\begin{array}{r}161.8 \\
1.15\end{array}$ & $\begin{array}{l}5.31 \\
0.03\end{array}$ \\
\hline $\begin{array}{l}\text { Urine } \\
\mu M^{2,3} \\
\mathrm{~g} / \mathrm{d}^{2,3,5,6}\end{array}$ & $\begin{array}{l}9.63 \\
0.557\end{array}$ & $\begin{array}{c}10.37 \\
0.617\end{array}$ & $\begin{array}{c}11.47 \\
0.701\end{array}$ & $\begin{array}{c}10.02 \\
0.587\end{array}$ & $\begin{array}{c}11.63 \\
0.644\end{array}$ & $\begin{array}{l}9.93 \\
0.557\end{array}$ & $\begin{array}{c}10.74 \\
0.629\end{array}$ & $\begin{array}{l}0.62 \\
0.03\end{array}$ \\
\hline $\begin{array}{l}\text { Total excreted carnitine } \\
\mathrm{g} / \mathrm{d}^{2,3,4,5,6,8}\end{array}$ & 1.52 & 1.78 & 1.92 & 1.62 & 1.87 & 1.54 & 1.79 & 0.04 \\
\hline
\end{tabular}

${ }^{1}$ Reported SEM is pooled across treatment groups.

${ }^{2}$ Linear effect of crystalline carnitine.

${ }^{3}$ Linear effect of $40 \%$ coating product.

${ }^{4} 40 \%$ coating product versus crystalline carnitine.

${ }^{5} 60 \%$ coating product versus crystalline carnitine.

${ }^{6}$ Linear effect of $60 \%$ coating product.

${ }^{7}$ Milk plus urine carnitine.

${ }^{8}$ Quadratic effect of $60 \%$ coating product.

* Significance for treatment contrasts declared at $P<0.05$.

or 40COAT increased plasma carnitine concentrations linearly $(P<0.001$ and $P=0.01$, respectively), whereas 60COAT tended to linearly increase plasma carnitine $(P=0.08$; Figure $2 \mathrm{~A})$. At 3.5 and $7 \mathrm{~g}$ of carnitine/d, LaCount et al. (1996b) reported 11 and $21 \%$ increases in plasma carnitine concentration, which is slightly less than the 14 and $42 \%$ increases resulting from feeding 3 and $6 \mathrm{~g}$ of crystalline/d in our study.

Despite the 40COAT and 60COAT products providing rumen protection in preliminary in vitro incubations (data not shown), crystalline increased plasma carnitine compared with both 40COAT $(P=0.03)$ and 60COAT $(P<0.001)$. Absence of additional bioavailability with RPC was also observed by White et al. (2002); feedlot lambs supplemented with either RPC (20\% L-carnitine) or unprotected carnitine (50\% L-carnitine) fed at equal L-carnitine concentrations in the diet had similar increases in plasma carnitine concentrations. Rumenprotected carnitine fed to lambs at doses ranging from 0.25 to $10 \mathrm{~g} / \mathrm{d}$ increased plasma carnitine concentrations relative to control, but no dose effect was present (Walker et al., 2005). Similar effects of crystalline and RPC observed across studies could potentially be due to hindered release of L-carnitine from protective coatings, affecting its intestinal absorption.

Excreted Carnitine. Milk carnitine concentrations were linearly increased by all sources. There was a tendency for a quadratic dose effect with 40COAT $(P=$ 0.08 ) with milk carnitine concentration being similar between control and $5 \mathrm{~g} / \mathrm{d}$, but increasing at $10 \mathrm{~g} / \mathrm{d}$. Crystalline increased milk carnitine concentration compared with 60COAT $(P<0.01)$ and tended to increase it compared with the 40COAT $(P=0.08)$. These effects were mirrored in daily milk carnitine output, with linear increases for all forms of supplementation (all $P<0.001)$, significantly greater amounts for crystalline than for 60COAT $(P<0.01)$, and a tendency for greater amounts for crystalline than for 40COAT $(P=$ $0.08)$.

Total milk carnitine concentrations were increased by ruminal or abomasal infusion and dietary administration of carnitine (LaCount et al., 1995, 1996a; Carlson et al., 2007a, 2007b). The quadratic effect observed by LaCount et al. (1996a) showed a large increase in milk carnitine concentration by 3,6 , and $12 \mathrm{~g} / \mathrm{d}$ infusion (258.8, 370.3, and $388.0 \mu M$, respectively), similar to the effect in plasma. Although carnitine supplementation effectively increased carnitine concentration in both plasma and milk, carnitine is present at a much greater concentration in milk $(138 \pm 5$ vs. $8.6 \pm 0.5$ $\mu M$ milk vs. plasma, respectively). This preferential transport of carnitine into milk has been previously documented in rats (Robles-Valdes et al., 1976) and dairy cattle (LaCount et al., 1995, 1996a; Carlson et al., 2007b).

Based on work in the rat, carnitine is transported in the mammary gland mainly by a sodium-dependent transporter with an estimated $\mathrm{K}_{\mathrm{m}}$ of $132 \mu M$, indicating that it is not saturated by plasma carnitine concentration under normal physiological conditions, thus allowing for continual flux of carnitine into the mammary epithelium (Shennan et al., 1998). The mammary epithelium also takes up carnitine by a nonsaturable sodium-independent process, but this 


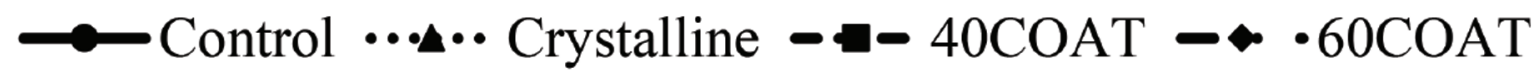
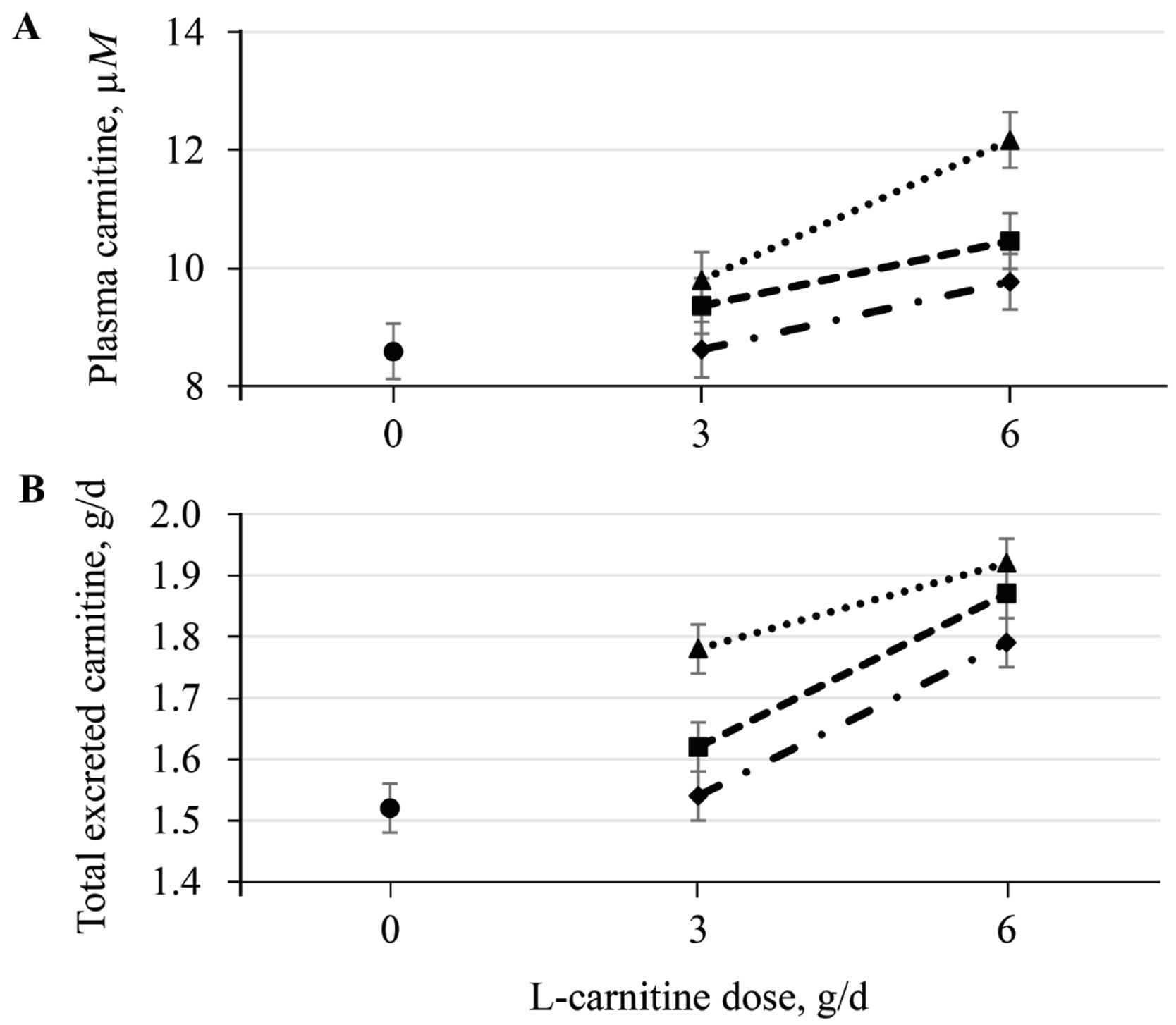

Figure 2. Relative bioavailability of crystalline carnitine, a $40 \%$ coating rumen-protected L-carnitine product (40COAT), or a $60 \%$ coating rumen-protected L-carnitine product (60COAT) fed to mid-lactation cows, compared with control. Crystalline carnitine was supplemented at 3 and $6 \mathrm{~g} / \mathrm{d}$ and doses of the rumen-protected products were fed to supply $6 \mathrm{~g}$ of L-carnitine/d. (A) Crystalline carnitine and 40COAT linearly increased plasma carnitine concentration $(P<0.001$ and 0.01 , respectively), whereas 60COAT tended to increase plasma carnitine $(P=0.08)$ however, crystalline increased plasma carnitine concentration more than 40COAT $(P=0.03)$ and 60COAT $(P<0.001)$. (B) Total excreted carnitine (milk plus urine carnitine) was linearly increased by all sources of carnitine $(P<0.001)$, but was greater for crystalline than $40 \mathrm{COAT}$ $(P=0.02)$ and 60COAT $(P<0.001)$. Also, a quadratic effect was observed for 60COAT $(P=0.03)$.

represents a small portion of carnitine uptake. Activity of the sodium-dependent carrier was greatest at the onset of lactation and decreased as lactation progresses, which corresponds to milk carnitine concentration (Shennan et al., 1998). Similarly, unsupplemented cows had greater milk carnitine concentrations at 2 wk of lactation than 6 wk (204 vs. $104 \pm 36 \mu M$; Carlson et al., 2007a). This pattern aligns with the carnitine requirements of the neonate, whose capacity to synthesize carnitine is initially low (Robles-Valdes et al., 1976). Dietary carnitine supplementation (50 and 100 $\mathrm{g} / \mathrm{d}$ ) increased early lactation milk carnitine concentration, but after supplementation ceased at 21 DIM, milk concentrations were no longer different at wk 6 of lactation (Carlson et al., 2007b). As expected, our observed milk carnitine concentrations were less than 
those reported in response to abomasal infusion of 20 $\mathrm{g} / \mathrm{d}$ or early lactation dietary supplementation at 50 or $100 \mathrm{~g} / \mathrm{d}$ (Carlson et al., 2007a,b).

Urine carnitine concentrations increased linearly with the crystalline $(P=0.03)$ and 40COAT $(P=$ $0.02)$ treatments. Urinary carnitine excretion increased linearly for all sources $(P<0.03)$. Similarly, urine carnitine concentration and output increased linearly with abomasal infusion (LaCount et al., 1996a). Although carnitine concentration increased linearly in plasma, milk, and urine, the marginal increase between 6 and 12 $\mathrm{g} / \mathrm{d}$ was lesser in plasma and milk and greater in urine. Thus, at high supplementation rates, excess carnitine was excreted in urine.

Total excreted carnitine (milk + urine carnitine) increased linearly for all carnitine sources $(P<0.0001$; Figure $2 \mathrm{~B}$ ) and was greater for crystalline carnitine than for 40COAT and 60COAT $(P=0.02$ and $<0.001$, respectively). A quadratic effect was observed for 60COAT $(P=0.03)$, as total excreted carnitine was similar for control and the $7.5 \mathrm{~g} / \mathrm{d}$ dose, but increased when $15 \mathrm{~g} / \mathrm{d}$ was supplied. Overall, total excreted carnitine increased with increasing supplementation.

Although carnitine excretion increased with supplementation, control cows excreted $1.52 \mathrm{~g}$ of carnitine per day, with $0.97 \mathrm{~g}$ of that excreted in milk. Previous work by LaCount et al. (1995) documented total excretion of $3.14 \pm 0.17 \mathrm{~g}$ of carnitine/d in early lactation multiparous cows, with $0.28,0.45$, and $2.41 \mathrm{~g} / \mathrm{d}$ lost in feces, urine, and milk, respectively. Despite the essential role of carnitine in hepatic lipid transport, plasma carnitine concentration and carnitine excreted in milk were not altered by feed-restriction-induced negative energy balance in mid-lactation cows (Carlson et al., 2007b). On the contrary, during negative energy balance in wk 2 of lactation carnitine excreted in milk was greater than in wk 6 once positive energy balance was reestablished (1.16 vs. $0.66 \pm 0.16 \mathrm{~g} / \mathrm{d}$; Carlson et al., 2007b). Because plasma carnitine concentration was lesser in early lactation (Carlson et al., 2007b), the increase in carnitine excreted in milk could be a function of catering to the neonate as discussed previously. Thus, these carnitine losses, coupled with reported declines in circulating carnitine concentration in early lactation, may indicate the need to supply bioavailable carnitine to maintain optimal carnitine availability for tissues, particularly in transition cows.

\section{CONCLUSIONS}

Carnitine is likely degraded in the rumen, and although the extent of degradation remains unknown, our findings clearly indicate abomasal administration of carnitine results in superior relative bioavailability compared with ruminal administration. The linear increase in plasma carnitine concentration in response to abomasal infusion does not support a limitation in intestinal absorption across the doses tested. Although crystalline and 40COAT were effective in linearly increasing carnitine concentrations, only subtle responses were observed for 60COAT, which were less than that for crystalline carnitine in plasma, milk, and urine. Ineffectiveness of rumen-protected products in increasing carnitine concentrations more than crystalline may have been due to over-encapsulation that hindered release of the carnitine and its absorption in the small intestine. Effective rumen protection of L-carnitine while maintaining intestinal availability needs further investigation.

\section{ACKNOWLEDGMENTS}

This is contribution no. 17-369-J from the Kansas Agricultural Experiment Station. The authors thank Lonza Inc. (Allendale, NJ) for their financial support of this research. The authors also thank Mike Scheffel and the staff at the Kansas State University Dairy Cattle Teaching and Research Center, graduate students Abigail Carpenter and Caroline Ylioja, and the undergraduate students assisting in animal care and feeding.

\section{REFERENCES}

Akbar, H., T. M. Grala, M. Vailati Riboni, F. C. Cardoso, G. Verkerk, J. McGowan, K. Macdonald, J. Webster, K. Schutz, S. Meier, L. Matthews, J. R. Roche, and J. J. Loor. 2015. Body condition score at calving affects systemic and hepatic transcriptome indicators of inflammation and nutrient metabolism in grazing dairy cows. J. Dairy Sci. 98:1019-1032.

Allen, M. S., B. J. Bradford, and M. Oba. 2009. Board-Invited Review: The hepatic oxidation theory of the control of feed intake and its application to ruminants. J. Anim. Sci. 87:3317-3334. https://doi .org/10.2527/jas.2009-1779.

Bobe, G., J. W. Young, and D. C. Beltz. 2004. Pathology, etiology, prevention, and treatment of fatty liver in dairy cows. J. Dairy Sci. 87:3105-3124.

Carlson, D. B., N. B. Litherland, H. M. Dann, J. C. Woodworth, and J. K. Drackley. 2006. Metabolic effects of abomasal L-carnitine infusion and feed restriction in lactating Holstein cows. J. Dairy Sci. 89:4819-4834.

Carlson, D. B., J. W. McFadden, A. D'Angelo, J. C. Woodworth, and J. K. Drackley. 2007a. Dietary L-carnitine affects periparturient nutrient metabolism and lactation in multiparous cows. J. Dairy Sci. 90:3422-3441.

Carlson, D. B., J. C. Woodworth, and J. K. Drackley. 2007b. Effect of L-carnitine infusion and feed restriction on carnitine status in lactating Holstein cows. J. Dairy Sci. 90:2367-2376.

Drackley, J. K. 1999. Biology of dairy cows during the transition period: The final frontier? J. Dairy Sci. 82:2259-2273.

Drackley, J. K., D. C. Beitz, and J. W. Young. 1991. Regulation of in vitro metabolism of palmitate by carnitine and propionate in liver from dairy cows. J. Dairy Sci. 74:3014-3024.

Drackley, J. K., H. M. Dann, G. N. Douglas, N. A. Janovick Guretzky, N. B. Litherland, J. P. Underwood, and J. J. Loor. 2005. Physiological and pathological adaptations in dairy cows that may in- 
crease susceptibility to periparturient diseases and disorders. Ital. J. Anim. Sci. 4:323-344.

Erfle, J. D., L. J. Fisher, and F. Sauer. 1971. Effect of infusion of carnitine and glucose on blood glucose, ketones, and free fatty acids of ketotic cows. J. Dairy Sci. 54:673-680.

Greenwood, R. H., E. C. Titgemeyer, G. L. Stokka, J. S. Drouillard, and C. A. Loest. 2001. Effects of L-carnitine on nitrogen retention and blood metabolites of growing steers and performance of finishing steers. J. Anim. Sci. 79:254-260.

Grummer, R. R. 1993. Etiology of lipid-related metabolic disorders in periparturient dairy cows. J. Dairy Sci. 76:3882-3896.

Harmeyer, J., and H. P. Sporleder. 2003. Interactions of the rumen with L-carnitine when used as a feed supplement. Acta Vet. Scand. 44(Suppl. 1):14.

Harper, P., C. E. Elwin, and G. Cederblad. 1988. Pharmakinetics of bolus intravenous and oral doses of L-carnitine in healthy subjects. Eur. J. Clin. Pharmacol. 35:69-75.

Humer, E., A. Khol-Parisini, B. U. Metzler-Zebeli, L. Gruber, and Q. Zebeli. 2016. Alterations of the lipid metabolome in dairy cows experiencing excessive lipolysis early postpartum. PLoS One 11:e0158633. https://doi.org/10.1371/journal.pone.0158633.

Ingvartsen, K. L., and J. B. Anderson. 2000. Integration of metabolism and intake regulation: A review focusing on periparturient animals. J. Dairy Sci. 83:1573-1597.

Jorritsma, R., H. Jorritsma, Y. H. Schukken, and G. H. Wentink. 2000. Relationships between fatty liver and fertility and some periparturient diseases in commercial Dutch dairy herds. Theriogenology 54:1065-1074.

LaCount, D. W., J. K. Drackley, and D. J. Weigel. 1995. Responses of dairy cows during early lactation to ruminal or abomasal administration of L-carnitine. J. Dairy Sci. 78:1824-1836.

LaCount, D. W., L. S. Emmert, and J. K. Drackley. 1996a. Dose response of dairy cows to abomasal administration of four amounts of L-carnitine. J. Dairy Sci. 79:591-602.

LaCount, D. W., L. D. Ruppert, and J. K. Drackley. 1996b. Ruminal degradation and dose response of dairy cows to dietary L-carnitine. J. Dairy Sci. 79:260-269.

Longo, N., C. Amat di San Filippo, and M. Pasquali. 2006. Disorders of carnitine transport and the carnitine cycle. Am. J. Med. Genet. C. Semin. Med. Genet. 142C:77-85.

Loor, J. J., H. M. Dann, R. E. Everts, R. Oliveira, C. A. Green, N. A. Janovick Guretzky, S. L. Rodriguez-Zas, H. A. Lewin, and J. K. Drackley. 2005. Temporal gene expression profiling of liver from periparturient dairy cows reveals complex adaptive mechanisms in hepatic function. Physiol. Genomics 23:217-226.

Louet, J. F., C. Le. May, J. P. Pegorier, J. F. Decaux, and J. Girard. 2001. Regulation of liver carnitine palmitoyltransferase I gene expression by hormones and fatty acids. Biochem. Soc. Trans. 29:310-316.

Mehlhorn, K. 2006. Studies on the use of carnitine in poultry. PhD Dissertation. Halle, Institute of Agricultural and Nutrition Sciences, Martin Luther University Halle-Wittenberg.

NRC. 2001. Nutrient Requirements of Dairy Cattle. 7th rev. ed. Natl. Acad. Press, Washington DC.

Rebouche, C. J. 1991. Quantitative estimation of absorption and degradation of a carnitine supplement by human adults. Metabolism 40:1305-1310.
Rebouche, C. J. 2004. Kinetics, pharmacokinetics, and regulation of L-carnitine and acetyl-L-carnitine metabolism. Ann. N. Y. Acad. Sci. 1033:30-41.

Rebouche, C. J., and C. A. Chenard. 1991. Metabolic fate of dietary carnitine in human adults: identification and quantification of urinary and fecal metabolites. J. Nutr. 121:539-546.

Robles-Valdes, D., J. D. McGarry, and D. W. Foster. 1976. Maternalfetal carnitine relationships and neonatal ketosis in the rat. J. Biol. Chem. 251:6007-6012.

Schlegel, G., J. Keller, F. Hirche, S. Geibler, F. J. Schwarz, R. Ringseis, G. I. Stangl, and K. Eder. 2012. Expression of genes involved in hepatic carnitine synthesis and uptake of dairy cows in the transition period and at different stages of lactation. BMC Vet. Res. 8:28.

Scholz, H., E. von Heimendahl, F. Menn, and A. Ahrens. 2014. Application of protected L-carnitine in dairy cows during transition and high lactation period. Glob. J. Sci. Front. Res. 14:41-46.

Schukken, Y. H., D. J. Wilson, F. Welcome, L. Garrison-Tikofsky, and R. N. Gonzalez. 2003. Monitoring udder health and milk quality using somatic cell counts. Vet. Res. 34:579-596.

Shennan, D. B., A. Grant, R. R. Ramsay, C. Burns, and V. A. Zammit. 1998. Characteristics of L-carnitine transport by lactating rat mammary tissue. Biochim. Biophys. Acta 1393:49-56.

Solhjoo, A., E. Rowghani, A. Bayat, and M. J. Zamiri. 2014. The effect of rumen protected L-carnitine on feedlot performance, carcass characteristics and blood metabolites in Iranian fat-tailed Ghezel lambs. Res. Opin. Anim. Vet. Sci. 4:192-197.

Tasdemir, A. R., M. Gorgulu, U. Serbester, and S. Yurtseven. 2011. Influence of dietary fat, L-carnitine and niacin on milk yield and milk composition of dairy cows in mid-lactation. Can. J. Agric. Sci. 45:123-129.

Valadares, R. F., G. A. Broderick, S. C. Valadares Filho, and M. K. Clayton. 1999. Effect of replacing alfalfa silage with high moisture corn on ruminal protein synthesis estimated from excretion of total purine derivatives. J. Dairy Sci. 82:2686-2696.

Vernon, R. G. 2005. Lipid metabolism during lactation: A review of adipose tissue-liver interactions and the development of fatty liver. J. Dairy Res. 72:460-469.

Walker, D. K., B. D. Lambert, and J. C. Woodworth. 2005. Effects of dietary ruminally protected L-carnitine on plasma metabolites in sheep following a sub-lethal ammonia challenge. J. Anim. Physiol. Anim. Nutr. (Berl.) 89:413-418.

Wensing, T., T. Kruip, M. J. H. Geelen, G. H. Wentink, and A. M. van de Top. 1997. Postpartum fatty liver in high-producing dairy cows in practice and in animal studies. The connection with health, production and reproduction problems. Comp. Haematol. Int. $7: 167-171$.

White, T. W., J. M. Fernandez, G. D. Harding, C. C. William, H. G. Bateman, T. D. Binder, P. T. Derouen, and M. A. Froetschel. 2002. Influence of L-carnitine on performance and ruminal and blood metabolites of grazing calves and finishing lambs. Prof. Anim. Sci. 18:59-65. 